\title{
A Novel Delay Based System for Type1 Diabetes using Xilinx System Generator 14.5
}

\author{
Anchana P Belmon, D.Jeraldin Auxillia
}

\begin{abstract}
In this paper an enhanced delay based system is proposed with a parallel execution of PID and Pseudo PID controllers using a Xilinx System Generator14.5. This paper presents simulation results on Direct synthesis, IMC and lambda based designs in both PID and Pseudo PID separately and parallel. The control methodology is suited for the people under Type 1 Diabetes Mellitus and it will maintain a glucose insulin homeostasis.
\end{abstract}

Keywords : Diabetes Mellitus, Pseudo PID controller,Pancreas.

\section{INTRODUCTION}

Diabetes Mellitus is a devastating, metabolic disorder glucose regulatory system, chronic disease. Type I and Type II are the two types of Diabetes Mellitus. 5-10\% of all the cases belong to Type I or juvenile diabetes. These involves associated with obesity, early mortality, family related and aged. Traditional methods of treatment involves diet, physical activity, blood glucose testing at home, taking insulin shots daily. Newer technologies involves Pancreas transplantation, pager sized device with tube called insulin pump inserted into the body, fully automated system called pseudo pancreas with an outer supply of insulin. Body receives glucose into the blood stream through food. Addition of glucose increases calcium ions. These calcium ions stimulates insulin to break glucose into useful particles.

After taking meal the glucose level of a healthy person is $(120-140 \mathrm{mg} / \mathrm{dl})$.When insulin is released from pancreas the glucose level becomes $(80-120 \mathrm{mg} / \mathrm{dl})$. By Bergman etal., (1981)[1],several glucose insulin dynamics was proposed.The model includes (i)metabolic processes (Pacini, etal., 1985)[2](ii)Pharmakinetic equations based on some non linear effects( Parker et al.; 2000)(iii)compartmental physiological equations (Sorensen; 1985). Lenart \& Parker,2001[4] had included the mathematical equations for the exercised effects also. (Lehmann, \& Deutsch, 1998; Halim et al.; 1993),gave predictions based on the diabetics and care. (Parker et al., 2000)[8] proposed a system for glucose regulation comprising of the hepatic glucose intake and production, insulin \& glucagon effects on hepatic glucose uptake,with a single pool modeling structure.

Revised Manuscript Received on December 30, 2019.

* Correspondence Author

Anchana P Belmon, Assistant Professor,Department of ECE Maria College of Engineering \& Technology, Attoor anchanabelmon@gmail.com

Dr. Jeraldin Auxillia, Professor,Department of ECESt.Xavier's jeraldin.auxillia@gmail.com

(C) The Authors. Published by Blue Eyes Intelligence Engineering and Sciences Publication (BEIESP). This is an open access article under the CC BY-NC-ND license (http://creativecommons.org/licenses/by-nc-nd/4.0/) autoimmune attack of beta cells. Type 2 Diabetes Mellitus is Catholic College of Engineering, Chunkankadai

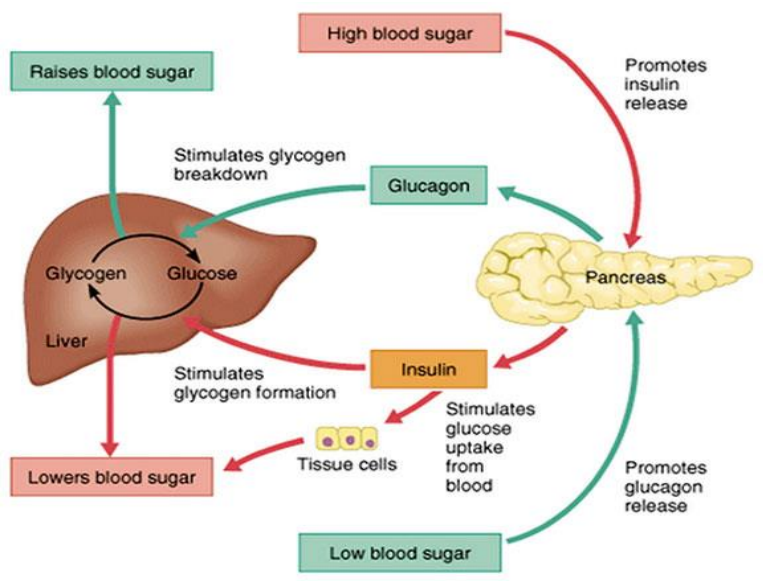

Fig.1.Blood glucose control system

Diabetes Mellitus is caused due to the intake of unhealthy food. Retinopathy, Nephropathy,[ peripheral neuropathy, Blindness, Kidney failure, foot ulcers, stroke, are the complications of Diabetes Mellitus.High blood sugar stimulates insulin secretion whereas low blood sugar stimulates glucagon production as in fig 1 .

\section{PSEUDO PANCREAS SYSTEM}

Pseudo Pancreas is a helpful tool for the prevention of diabetes and attempts to use control system tools for the design.

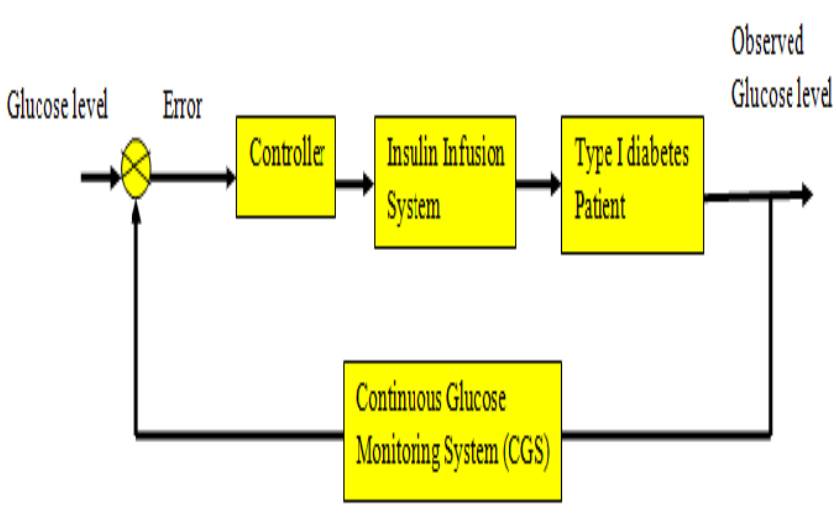

Fig.2..Pseudo Pancreas system

Pseudo Pancreas system (Artificial Pancreas System or APS) helps to maintain normal glucose homeostasis. Pseudo Pancreas consists of Continuous Monitoring System (CMS), insulin pump and controller to calculate the required amount of insulin infusion rate. 
Artificial Pancreas or Pseudo Pancreas regulates blood glucose concentration using continuous glucose monitoring sensor continuously at a sampling time of every 5 minutes. The automatic control system adjusts to every modifications depending on meal, exercise, illness etc based on the patient model. Pancreas consists of mainly three types of cells namely alpha cells, Beta cells, Delta Cells.Alpha cells, present at the periphery of islets of Langerhans are responsible for Glucagon production. Beta Cells, present at the centre of islets of Langerhans produce insulin which regulates macromolecules,Amylin which helps in gastric emptying.Delta Cells produce Sumatostatin helpful in regulation of other pancreatic hormones. Artificial Pancreas response to every minute changes in the blood glucose level and release as much insulin based on the nature of the body as in the fig. 2 .

$$
\begin{gathered}
\text { III. MATHEMATICAL } \\
\text { MODEL } \\
\frac{d G(t)}{d t}=G_{\gamma}-h_{2}(G(t))-h_{3}\left\{G(t) h_{4}\left(I\left(t-\tau_{2}\right)\right)+h_{5}\left(I\left(t-\tau_{0}\right)\right\}\right. \\
\frac{d I_{p}(t)}{d t}=b h_{1}\left(G\left(t-\tau_{1}\right)\right)-\frac{I_{i}}{t_{i}} \frac{d I_{i}(t)}{d t}
\end{gathered}
$$

For the possible calculation and ease of analysis,we prefer mathematical models[Mountcastle, 1968] as per equation (1) afid (2) with the following considerations:

1.Blood insulin and blood glucose increase are in equal proportions

2.The regulated variable is always blood glucose.

Expansion of equation (1) and (2) are

$\mathrm{I}(\mathrm{t})$-Concentration of Insulin in cellular fluids

$\mathrm{G} \gamma$-rate of absorption of glucose in the blood stream.

$\mathrm{G}(\mathrm{t})$-blood glucose concentration

$\tau_{1}, \tau_{2}, \tau_{3}$-delays corresponding to the liver and intercellular space,beta cells and intercellular space,glucose and liver respectively.

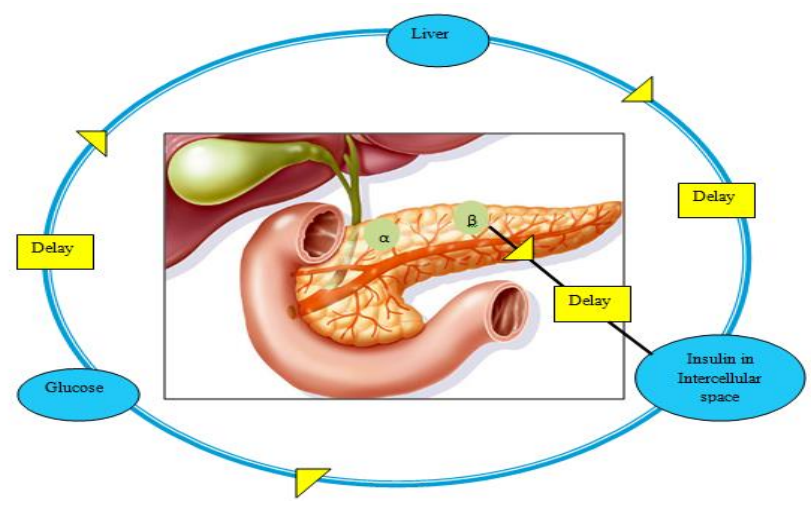

Fig.3 Delay based glucose insulin homeostasis

\section{A. PID Controller}

PID controller consists of three basic modes namely:Proportional(P),Integral (I)and Derivative(D).The use of proportional, Integral,Derivative controller stabilizes the gain, reduces the steady state error and reduces the rate of change of error respectively. The output of PID controller on taking laplace transform with zero initial conditions is

$$
U(s)=k_{p}\left[1+\frac{1}{T_{i} s}+T_{d} s\right]
$$

Where $K_{p}$-Proportional gain, $T_{i}$-Integral time, $T_{d}$-Derivative time

\section{B. PSEUDO-PID Controller}

Pseudo-PID gives a platform for FPGA, DSP and any other hardware platforms with single tuning parameter $\mathrm{K}_{\mathrm{c}}$ Ziegler-Nichols tuning rules develops an efficient control algorithm.

The PID controller can be represented as

$\mathrm{U}(\mathrm{t})=\mathrm{K}_{\mathrm{c}}\left[\mathrm{e}(\mathrm{t})+\frac{T_{s}}{T_{i}} \sum_{i=1}^{t} e(t)+\frac{T_{d}}{T_{s}}[e(t)-e(t-1)]\right](4)$

Incremental PID can be represented as

$\left.\mathrm{U}(\mathrm{t})=\mathrm{U}(\mathrm{t}-1)+\mathrm{K}_{q}[\mathrm{e}(\mathrm{t})-\mathrm{e}(\mathrm{t}-1)]+\mid \frac{T_{s}}{T_{i}} e(t)+\frac{T_{d}}{T_{s}}[e(t)-2 e(t-1)]+e(t-2)\right]$

In order to avoid loop saturation,

(i)Substitute proportional,integral and derivative terms with $\mathrm{e}(\mathrm{t})=-\mathrm{y}(\mathrm{t})$

(ii)Integral term can be denoted as $\mathrm{e}(\mathrm{t})=\mathrm{y}_{\mathrm{r}}(\mathrm{t})-\mathrm{y}(\mathrm{t})$

Pseudo-PID improves stability and regulates closed -loop performance proposed by H. A. Fertik (Seborg et al., 1989) and J. G. Ziegler and N. B. Nichols (Visioli, 2006).

We obtain the relations

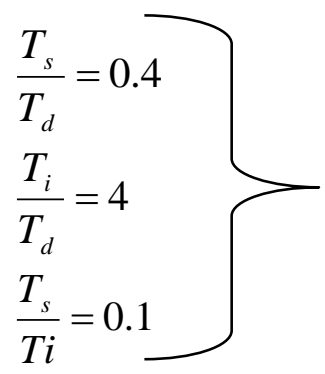

Thus the Pseudo-PID controller contains a single tuning parameter and is represented as $\mathrm{U}(\mathrm{t})=\mathrm{U}(\mathrm{t}-1)+\mathrm{K}_{\mathrm{c}}\left\{0.1 \mathrm{y}_{\mathrm{r}}(\mathrm{t})-3.6 \mathrm{y}(\mathrm{t})+6 \mathrm{y}(\mathrm{t}-1)-2.5 \mathrm{y}(\mathrm{t}-2)\right\}$

These involves autoimmune attack of beta cells.

\section{PROCEDURE FOR IMPLEMENTATION}

The proposed work is done in a MATLAB-SIMULINK based platform. The laplace transform of the model is reduced using half rule. Delay is calculated on each parameters of the model considering all initial conditions.PID and PSEUDOPID controllers are developed for the model with controllers of direct synthesis, IMC based controllers and lambda based controllers. Execution is done on parallelly with a prudent support of all controllers. Xilinx simulink blocks help in simulation of glucose insulin control metabolism. System generator help in the conversion of files to hardware description language. 


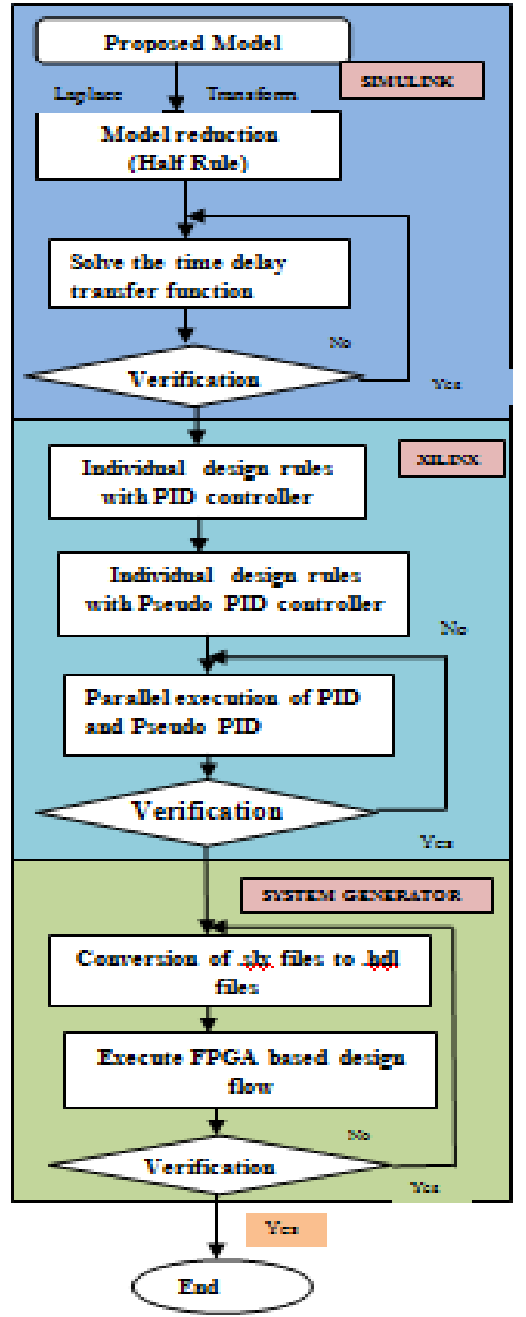

Fig.4 FPGA implementation for the proposed model.

\section{PROPOSED WORK}

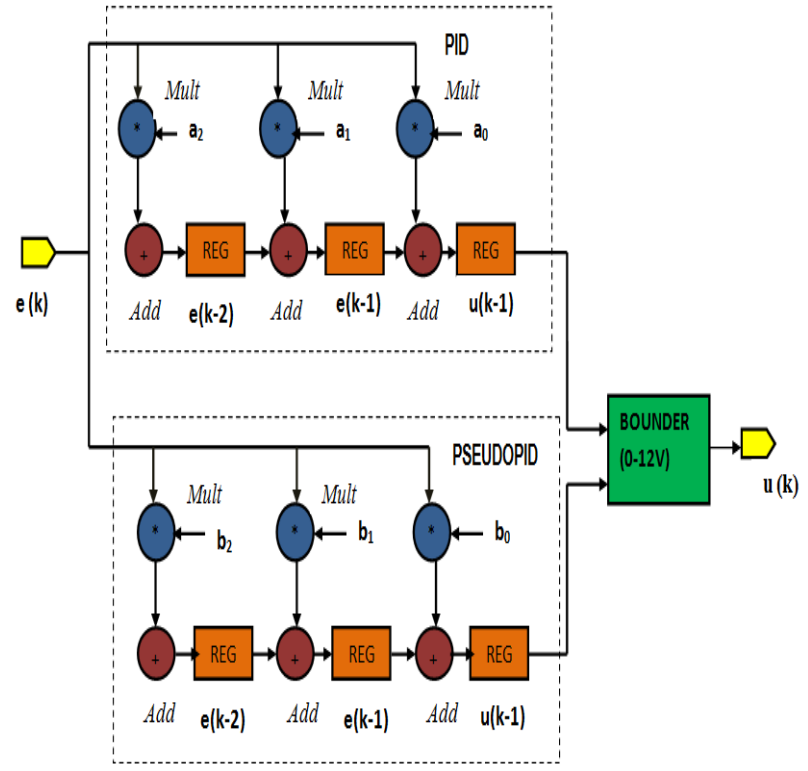

Fig.5 Mathematical implementation strategy

Mathematical model includes the parallel execution of PID and Pseudo PID controller based on FIR filter design methodology with a bounder of $(0-12 \mathrm{~V})$. The transfer function of each system is given by $\mathrm{D}(\mathrm{z})=(\mathrm{Y}(\mathrm{z}) / \mathrm{U}(\mathrm{z}))$

$$
\mathrm{D}(\mathrm{z})=\frac{a_{0}+a_{1} z^{-1}+a_{2} z^{-2}}{b_{0}+b_{1} z^{-1}+b_{2} z^{-2}}
$$

$\mathrm{a}_{0}, \mathrm{a}_{1}, \mathrm{a}_{2}, \mathrm{~b}_{0}, \mathrm{~b}_{1}, b_{2}$ are determined by the process of tuning. The system input can be predicted in the format of $\mathrm{U}(\mathrm{k})=u(k-1)+a_{0} e(k)+a_{1} e(k-1)+a_{2} e(k-2)(8)$

\section{IMC based PID Controller}

IMC based controller has a single tuning factor $K_{c}$ which determines the speed of the system.IMC design procedure involves

(i)Design the internal model controller with an equivalent controller in standard form.

(ii)Use a Padé approximation for time-delays in order to find a PID-type control law.

(iii)Compare the IMC-based PI, PID and improved PI controllers for first-order + timedelay processes.

The values of $\mathrm{a}_{0}, \mathrm{a}_{1}, \mathrm{a}_{2}$ for PID controller is 27.2,-28.34,1.6 repectively and for Pseudo PID controller is $\mathrm{a}_{0}=32.88, \mathrm{a}_{1}=-37.42, \mathrm{a}_{2}=6.512$.

\section{Lambda based PID Controller}

Lambda based design rules provide a sound nonoscillatory response.Tuning of parameters on model based method are mainly due to $\lambda$ while $K_{c}, T_{i}$ are not considered.

\section{E. Direct Synthesis based PID Controller}

Direct Synthesis deals with the desired closed loop transfer function. Incorporation of performance requirements are done directly. The values of $\mathrm{a}_{0}, \mathrm{a}_{1}, \mathrm{a}_{2}$ for PID controller is 25.41,-25.43,0.0259and for Pseudo PID controller is $\mathrm{a}_{0}=39.433, \mathrm{a}_{1}=-50.495, \mathrm{a}_{2}=13.05$ repectively.

\section{IMPLEMENTATION}

\section{A. Simple Glucose transfer function Evaluation}

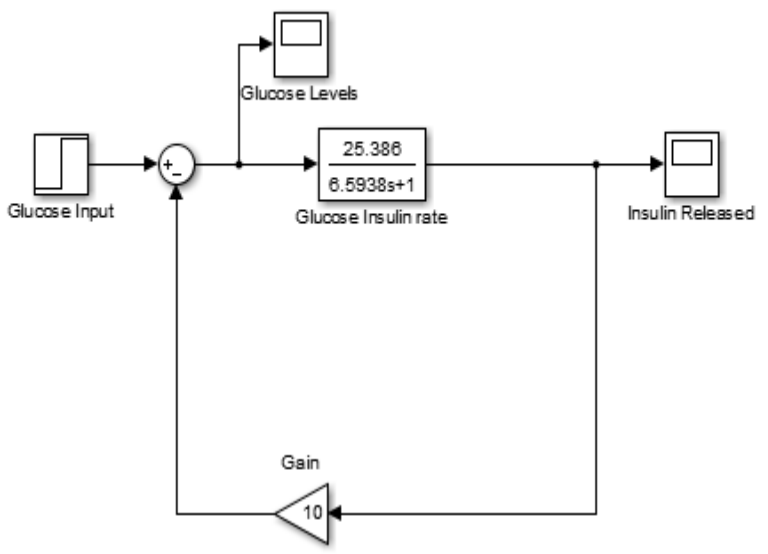

Fig.6 Transfer function evaluation for the entire system

The transfer function evaluation of the entire system is defined using the transfer function as $\frac{25.386}{6.5938 s+1}$. 


\section{B. Parallel Execution of delay model using Xilinx System Generator}

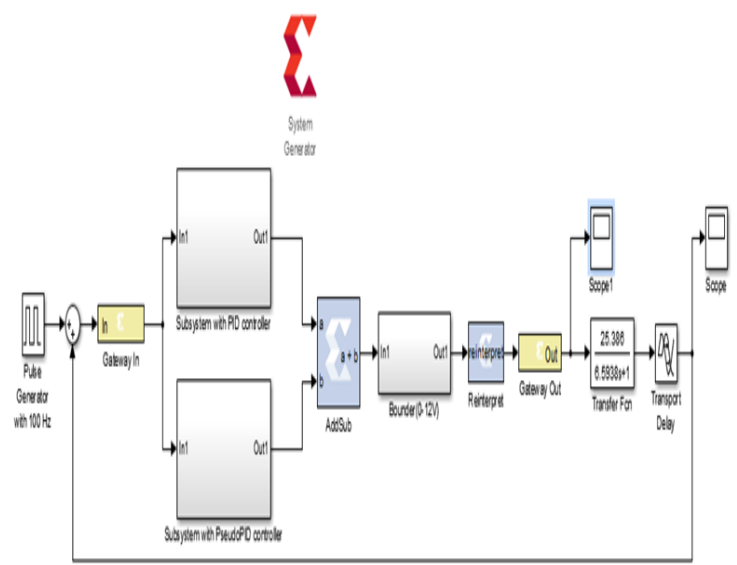

Fig.7 Xilinx system generator for entire system

Xilinx system generator generate core for Xilinx FPGAs to generate HDL codes. This rapid prototyping of FPGA design is used to find number of flipflops,slices,datapath delay etc.

\section{RESULTS AND DISCUSSIONS}

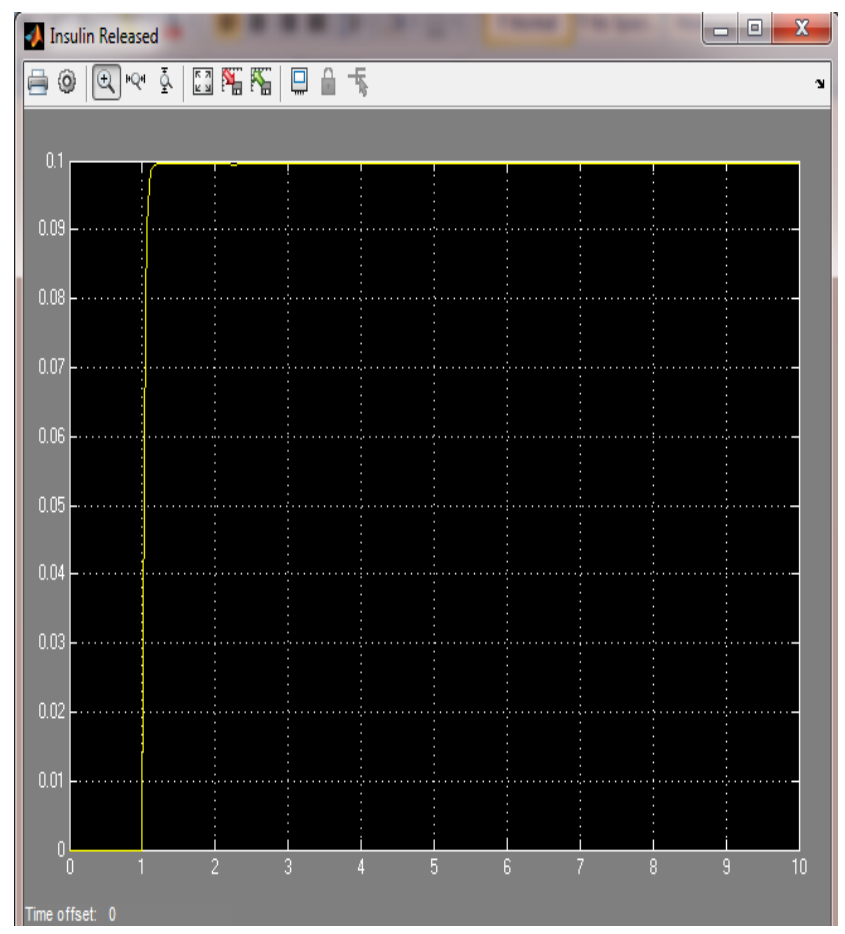

Fig.8 insulin released

Fig. 8 shows the amount of insulin released per time for the delay based system.Fig.9 shows the raise in glucose value as per the insulin variation.Fig.10 shows the comparison of direct synthesis,IMC,Lambda with and withoiut feedbacks.IMC based controller shows some minor oscillations in the control action.Here the insulin infusion rate varies depending on the time in seconds.As the bounder varies from $(0-12 \mathrm{~V})$, the values are restricted to $12 \mathrm{~V}$.The oscillated voltage ranges between $(0-4) \mathrm{V}$.

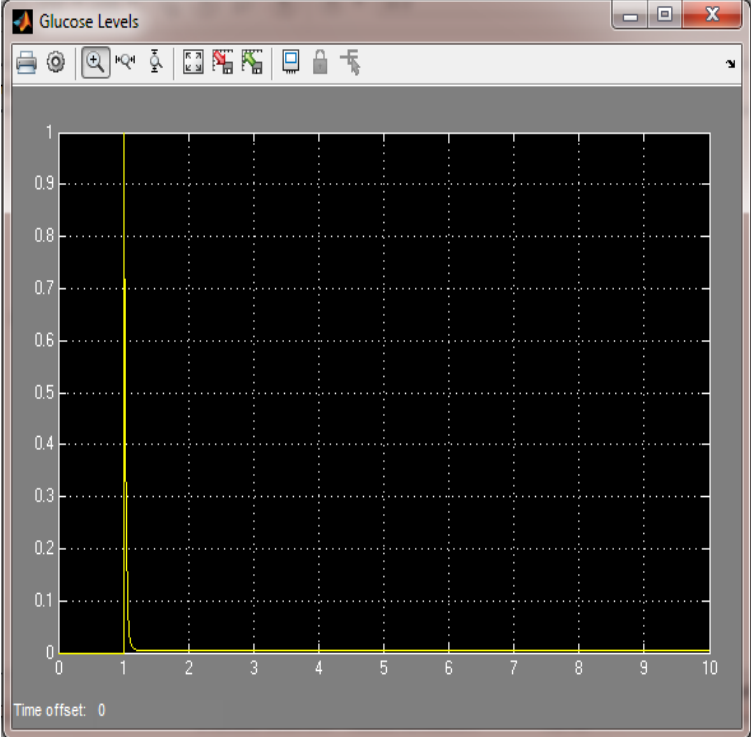

Fig.9 Glucose Produced
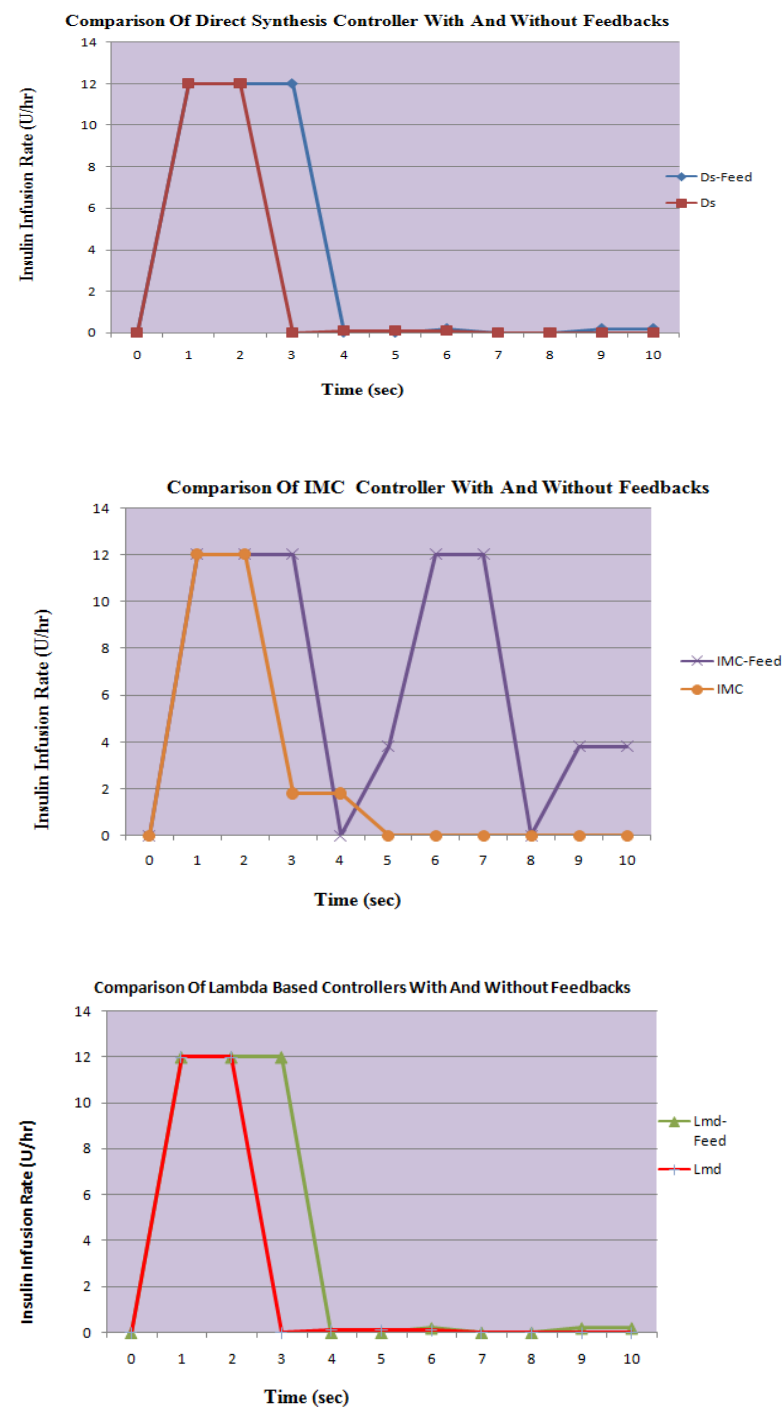

Fig.10 Comparison of various controllers with and without feedbacks 


\begin{tabular}{|c|c|c|c|c|c|c|}
\hline \multicolumn{7}{|c|}{ INDIVIDUAL PERFORMANCE ANALYSIS } \\
\hline Comparison & $\begin{array}{l}\text { Direct Synthesis } \\
\text { with PID }\end{array}$ & $\begin{array}{l}\text { Direct Synthesis } \\
\text { with Pseudo-PID }\end{array}$ & $\begin{array}{l}\text { IMC with } \\
\text { PID }\end{array}$ & $\begin{array}{l}\text { IMC with } \\
\text { Pseudo-PID }\end{array}$ & $\begin{array}{l}\text { Lambda } \\
\text { Based PID }\end{array}$ & $\begin{array}{l}\text { Lambda } \\
\text { Based } \\
\text { Pseudo-PID }\end{array}$ \\
\hline Number of Slice Registers & 108 & 117 & 117 & 115 & 117 & 117 \\
\hline Number used as Flip flops & 106 & 114 & 116 & 114 & 116 & 116 \\
\hline Number of Slice LUTs & 344 & 392 & 404 & 402 & 391 & 418 \\
\hline Number used as logic & 317 & 357 & 368 & 368 & 355 & 382 \\
\hline Number using o6 output only & 280 & 311 & 327 & 327 & 309 & 345 \\
\hline Number using o5 output only & 3 & 5 & 2 & 2 & 1 & 6 \\
\hline Number using 05 and o6 & 34 & 41 & 39 & 39 & 40 & 36 \\
\hline $\begin{array}{l}\text { Number used exclusively as } \\
\text { route thrus }\end{array}$ & 27 & 35 & 36 & 34 & 36 & $\overline{36}$ \\
\hline $\begin{array}{l}\text { Number with same slice carry } \\
\text { load }\end{array}$ & 27 & 34 & 36 & 34 & 36 & 36 \\
\hline Number of occupied slices & 124 & 136 & 145 & 145 & 111 & 145 \\
\hline Number of LUT Flip flops & 344 & 392 & 405 & 403 & 391 & 418 \\
\hline $\begin{array}{l}\text { Number used as unused Flip } \\
\text { flop }\end{array}$ & 236 & 276 & 288 & 288 & 274 & 301 \\
\hline $\begin{array}{l}\text { Number of fully used LUT-FF } \\
\text { Pairs }\end{array}$ & 108 & 116 & 116 & 114 & 117 & 117 \\
\hline $\begin{array}{l}\text { Number of Slice register sites } \\
\text { cost to control set restrictions }\end{array}$ & 6 & 6 & 4 & 6 & 4 & 4 \\
\hline Number of bonded IOB's & 55 & 57 & 57 & 57 & 57 & $\overline{57}$ \\
\hline $\begin{array}{l}\text { Average Fanout of Non-clock } \\
\text { Nets }\end{array}$ & 3.54 & 3.37 & 3.54 & 3.55 & 3.38 & 3.59 \\
\hline Total Memory Usage & $146308 \mathrm{~Kb}$ & $147268 \mathrm{~Kb}$ & $147012 \mathrm{~Kb}$ & $146500 \mathrm{~Kb}$ & $147528 \mathrm{~Kb}$ & $147524 \mathrm{~Kb}$ \\
\hline Number of External IOBs & $\begin{array}{l}55 \text { out of } \\
200(27 \%)\end{array}$ & 57 out of $200(28 \%)$ & $\begin{array}{l}55 \text { out of } \\
200(27 \%)\end{array}$ & $\begin{array}{l}57 \text { out of } \\
200(28 \%)\end{array}$ & $\begin{array}{l}57 \text { out of } \\
200(28 \%)\end{array}$ & $\begin{array}{l}57 \text { out of } \\
200(28 \%)\end{array}$ \\
\hline Slack/set up path & $6.308 \mathrm{~ns}$ & $6.469 \mathrm{~ns}$ & $6.463 \mathrm{~ns}$ & $6.534 \mathrm{~ns}$ & $6.652 \mathrm{~ns}$ & $6.652 \mathrm{~ns}$ \\
\hline Data Path Delay & $3.586 \mathrm{~ns}$ & $3.510 \mathrm{~ns}$ & $3.509 \mathrm{~ns}$ & $3.439 \mathrm{~ns}$ & $3.348 \mathrm{~ns}$ & $3.278 \mathrm{~ns}$ \\
\hline Clock Path Skew & $-0.071 \mathrm{~ns}$ & $0.014 \mathrm{~ns}$ & $0.007 \mathrm{~ns}$ & $0.008 \mathrm{~ns}$ & $-0.035 \mathrm{~ns}$ & $-0.035 \mathrm{~ns}$ \\
\hline Minimum Period & $3.692 \mathrm{~ns}$ & $3.531 \mathrm{~ns}$ & $3.537 \mathrm{~ns}$ & $3.466 \mathrm{~ns}$ & $3.348 \mathrm{~ns}$ & $3.348 \mathrm{~ns}$ \\
\hline
\end{tabular}

Fig.11 shows the comparison of Direct Synthesis with PID and Pseudo PID,IMC with PID and Pseudo PID,Lambda based synthesis with PID and Pseudo PID respectively with the effective analysis on the model individually.Average Fan out,number of bonded IOB's,number of external IOB's,data Path delay,clock path skew,minimum period etc.

\begin{tabular}{|c|c|c|c|c|c|c|c|c|c|}
\hline \multicolumn{10}{|c|}{ PARALLEL DESIGN ANALYSIS } \\
\hline \multirow[t]{2}{*}{ COMPARISON } & \multicolumn{3}{|c|}{ DIRECT SYNTHESIS } & \multicolumn{3}{|c|}{ IMC } & \multicolumn{3}{|c|}{ LAMBDA BASED DESIGN } \\
\hline & Used & Available & Utilization & Used & Available & Utilization & Used & Available & Utilization \\
\hline No. of Slice Registers & 235 & 106,400 & $1 \%$ & 240 & 106,400 & $1 \%$ & 239 & 106,400 & $1 \%$ \\
\hline Number used as Flip-flops & 230 & & & 234 & & & 238 & & \\
\hline Number used as AND/OR logics & 5 & & & 6 & & & 1 & & \\
\hline Number of Slice LUTs & 731 & 53,200 & $1 \%$ & 754 & 53,200 & $1 \%$ & 798 & 53,200 & $1 \%$ \\
\hline Number used as logic & 677 & 53,200 & $1 \%$ & 693 & 53,200 & $1 \%$ & 732 & 53,200 & $1 \%$ \\
\hline Number using 06 output only & 627 & & & 649 & & & 688 & & \\
\hline Number using 05 output only & 16 & & & 18 & & & 21 & & \\
\hline Number using 06 and 05 output only & 34 & & & 26 & & & 23 & & \\
\hline Number used Exclusively as route Thrus & 54 & & & 61 & & & 66 & & \\
\hline Number with same slice carry load & 54 & & & 61 & & & 66 & & \\
\hline Number of occupied Slices & 222 & 13,300 & $1 \%$ & 247 & 13,300 & $1 \%$ & 252 & 13,300 & $1 \%$ \\
\hline Number of LUT Flip -flops pair used & 731 & & & 754 & & & 798 & & \\
\hline Number of fully used LUT FF pairs & 235 & 731 & $32 \%$ & 240 & 754 & $31 \%$ & 239 & 798 & $29 \%$ \\
\hline $\begin{array}{l}\text { Number of Slice Register sites lost to control } \\
\text { set restrictions }\end{array}$ & 2 & 106,400 & $1 \%$ & 6 & 106,400 & $1 \%$ & 2 & 106,400 & $1 \%$ \\
\hline Number of bonded IOB's & 58 & 200 & $29 \%$ & 60 & 200 & $30 \%$ & 60 & 200 & $30 \%$ \\
\hline \multicolumn{9}{|l|}{ Average Fan out of Non-Clock Nets } & 3.54 \\
\hline Total Memory Usage & \multicolumn{3}{|c|}{$149252 \mathrm{~KB}$} & \multicolumn{3}{|c|}{$149572 \mathrm{~KB}$} & \multicolumn{3}{|c|}{$149252 \mathrm{~KB}$} \\
\hline Number of External IOB's & \multirow{2}{*}{\multicolumn{3}{|c|}{$\begin{array}{l}58 \text { out of } 200 \\
222 \text { out of } 13,300\end{array}$}} & \multicolumn{3}{|c|}{60 out 200} & \multicolumn{3}{|c|}{60 out of 200} \\
\hline Number of Slices & & & & & & & 252 ou & of 13,300 & \\
\hline Number of Slice Register & \multicolumn{3}{|c|}{235 out of 106400} & \multicolumn{3}{|c|}{240 out of 106400} & \multicolumn{3}{|c|}{239 out of 106400} \\
\hline Slack/Set up path & \multicolumn{3}{|c|}{$6.339 \mathrm{~ns}$} & \multicolumn{3}{|c|}{$6.467 \mathrm{~ns}$} & \multicolumn{3}{|c|}{ 6.433ns } \\
\hline
\end{tabular}




\begin{tabular}{|l|l|l|l|}
\cline { 2 - 4 } Data Path Delay & $3.582 \mathrm{~ns}$ & $3.437 \mathrm{~ns}$ & $3.540 \mathrm{~ns}$ \\
\hline Clock Path Skew & $-0.044 \mathrm{~ns}$ & $-0.061 \mathrm{~ns}$ & $0.008 \mathrm{~ns}$ \\
\hline Minimum Period & $3.661 \mathrm{~ns}$ & $3.533 \mathrm{~ns}$ & $3.567 \mathrm{~ns}$ \\
\hline
\end{tabular}

Fig.11 Parallel Design Analysis

Fig.11 shows parallel design analysis of the system having PID,Pseudo PID controllers in parallel. Parallel execution is better compared to individual controllers because of the variation in system function changes.

\section{CONCLUSION}

Thus the parallel implementation performes well compared to the individual implementations in terms of time and speed.

\section{REFERENCES}

1. $\quad$ Š. Kozák, "Development of control engineering methods and their applications in industry" In 5th Int. Scientific-Technical Conference Process Control 2002. Kouty nad Desnou, Czech Rep., 2002.

2. M. Kocúr, "HW realizácia PID algoritmov na báze FPGA štruktúr," Slovak University of Technology in Bratislava, Bratislava.

3. B. Picinbono, M. Bendir, "Some properties of lattice autoregressive filters", IEEE Trans. Acoust. Speech Signal Process, 34, 342-349., 1986.

4. A. M. Oppenheim,R. W. Schaffer, "Discrete-Time Signal Processing." Prentice-Hall, Englewood Cliffs,1989.

5. Åström, K. and Hägglund, T. (1995). PID controllers. Research Triangle Park, N.C.: International Society for Measurement and Control.

6. Baotić, M., Borrelli, F., Bemporad, A. and Morari, M. (2008). Efficient On-Line Computation of Constrained Optimal Control. SIAM Journal on Control and Optimization, 47(5), 2470-2489

7. J.Cigánek, Š.Kozák, "Robust controller design techniques for unstable systems" In Int. conf. Cybernetics and informatics, Vyšná Boca, Slovak Rep. 2010.

8. Ü. Nurges, "Robust pole assignment via reflection coefficients of polynomials". Automatica, 42(7), 1223 - 1230, 2006.

\section{AUTHORS PROFILE}

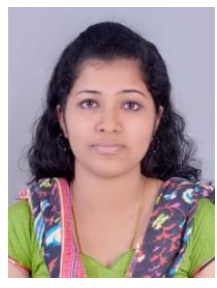

Anchana P Belmon, Assistant Professor,Department of ECE Maria College of Engineering \& Technology, Attoor anchanabelmon@gmail.com

She has graduated in Electronics and Communication Engineering from Narayana Guru College of

Engineering in 2011 and secured 44 th university rank. She received her M.E Degree in Applied Electronics from the St.Xaviers Catholic College of Engineering in 2013 with 10 th university rank. She is currently working as assistant professor in Maria College of Engineering and Technology and doing part time research under anna university.

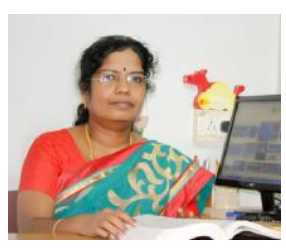

Dr. Jeraldin Auxillia, Professor,Department of ECE St.Xavier's Catholic College of Engineering, Chunkankadai jeraldin.auxillia@gmail.com

She has graduated in Instrumentation and Control Engineering from Government College of Technology, Coimbatore in 1988. She received her M.E Degree in Control and Instrumentation from the College of Engineering, Guindy, Anna University, Chennai in 2002. She completed her Ph.D from Anna University Chennai in 2012 in the area of controller design. She teaches Under Graduate and Post Graduate courses for the past twenty seven years. Her area of interest includes System identification and controller design. She is a Life member of ISTE. 